\section{First ever animal patent issued in United States}

\section{- Harvard receives patent for myc mouse - Furore from opponents of animal patent}

\section{Washington}

ThE US Patent and Trademark Office (PTO) last week granted the first patent in the world for a genetically altered animal. The patent was awarded to Harvard University based on the development in 1984 by Philip Leder at Harvard and Timothy Stewart, now at Genentech, of a mouse which readily expresses the myc oncogene, and is extremely susceptible to the development of tumours.

The myc oncogene occurs naturally in many animals, including man, and its genetic sequence is substantially the same in all species. Expression of the myc oncogene has been implicated in the development of breast cancer.

The Harvard patent's sweepingly broad main claim covers any transgenic nonhuman animal whose genome contains an activated oncogene sequence that has been introduced into the animal by recombinant DNA techniques. Additional claims specify that the animal could be a rodent, such as a mouse; that the oncogene sequence could be one that occurs naturally in the animal, but which is inserted with a different transcriptional promoter into a different place in the animal's genome; and that the oncogene sequence could be controlled by a promoter switched on by agents such as hormones. Animals which contain oncogene sequences controlled by the mouse mammary tumour virus promoter, the Rous sarcoma virus promoter and any synthetic promoter are specifically covered by the patent.

A patent covering a higher animal has been expected since last year when the PTO announced it would not refuse to issue a patent simply because the 'invention' was an animal. The PTO based its interpretation of patentable subject matter on the 1980 Supreme Court ruling in Diamond versus Chakrabarty that allowed the patenting of microbes, and several plant patent cases.

In the 1980 ruling, the Supreme Court decided that "everything under the Sun made by man" is eligible for a patent, as long as an invention is useful, novel and non-obvious, and the inventor describes the invention sufficiently to enable someone skilled in the art to practise it and enlarge upon it when the patent expires.

The PTO's announcement sparked a flurry of controversy over the ethical implications of designating inventors for higher life forms. For the past year, animal rights groups, farming organiza- tions and religious leaders have spoken out against the new policy, and encouraged Congress to establish a moratorium on the patenting of animals until the ethical and economic consequences can be worked out. Farmers' organizations, backed up by anti-biotechnology activist Jeremy Rifkin, have been especially active in their lobbying efforts. A letter which leaked out of the PTO earlier this year stated that the reproduction of patented animals - such as improved breeds of livestock - would "seem to be an infringement" unless farmers paid royalties to the originators of the animals (see Nature 331, 651; 1988).

Last year, legislation to place a twoyear moratorium on the patenting of animals was introduced into both houses of Congress, and nearly passed into law as an amendment to the 1987 budget supplemental appropriations bill. Legislation to enact a moratorium has been introduced into the House of Representatives again this year by Representative Charles Rose (Democrat, North Carolina). After the Harvard patent issued last week, Rose signed a letter along with 31 other representatives stating that "the patent office has been given no clear and certain signal from Congress... [that animal patenting] ... is acceptable public policy", and requesting that the PTO "immediately halt" the granting of additional animal patents until Congress has considered the issue.

Leder, Stewart and Paul Pattengale of the University of Southern California developed the ' $m y c$ mouse' which led to the patent as a means to test whether the development of cancer results from the direct expression of one or more oncogenes, or whether additional agents such as mutagens or inducing hormones are required.

They constructed several genetic sequences containing the $m y c$ oncogene and promoter regions which would allow the gene to be expressed freely, and inserted them into fertilized mouse eggs. If only the myc oncogene was necessary for the development of cancer, cancer would have resulted uniformly in the breast tissue of the transgenic mice. Instead, tumours developed individually - but at a much higher rate than would be found in a normal mouse - suggesting outside substances are at work.

Harvard has granted an exclusive licence to Du Pont for the transgenic 'myc mouse'.

\section{Killed HIV treatment} in clinical trials

A NOVEL approach to curtail disease in patients already infected with human immunodeficiency virus (HIV), the virus that causes AIDS, is under way at the University of Southern California medical school.

The treatment was developed by Immune Response Corporation, formed last year by Jonas Salk, and involves injecting patients with HIV previously irradiated to destroy its DNA. Salk's theory is that injecting previously infected individuals with additional killed HIV will boost their immune response (see Nature 327,473 ; 1987).

The trial is said to involve between 10 and 15 people who have early symptoms of AIDS. A similar post-exposure vaccine trial which involves the injection of killed simian immunodeficiency virus (SIV) in rhesus monkeys is being conducted by Paul Luciw at the University of California at Davis. Luciw reports that no immune sideeffects have yet appeared in the monkeys, and that they have elevated antibody titres to SIV after six months and two booster injections.

The results of the Salk trial are expected to be presented at the Fourth International Conference on AIDS to be held in Stockholm, Sweden, this summer. C.E.

\section{Ethical questions of tissue transplant}

THE Department of Health and Human Services has put the brakes on plans of the National Institutes of Health (NIH) to transplant human neuronal tissue from induced abortions into patients with Parkinson's disease, a treatment already tried in Mexico (and in the United Kingdom, see p.667).

In a memorandum dated 22 March 1988 to NIH director James Wyngaarden, assistant secretary for health Robert Windom wrote that he was withholding approval of the proposed experiment and future experiments involving fetal tissue from induced abortions until NIH established an outside advisory committee to review such research.

Use of fetal tissue from induced abortions raises moral and ethical questions. Windom's memorandum raises several of these. By seeking informed consent from a pregnant woman, is a researcher in fact responsible for 'inducing' her to consent to an abortion? Windom wants the outside advisory committee to examine these and other issues.

This does not end research on fetal tissue at NIH. The memorandum does not include tissue from spontaneous abortions and stillbirths. 